\title{
The Mystique of Dreams
}





\title{
G. William Domhoff
}

\section{The Mystique of Dreams}

\author{
A Search for Utopia \\ through Senoi Dream Theory
}

University of California Press

Berkeley Los Angeles London 
University of California Press

Berkeley and Los Angeles, California

University of California Press, Ltd.

London, England

(c) 1985 by

The Regents of the University of California

Printed in the United States of America

$\begin{array}{lllllllll}1 & 2 & 3 & 4 & 5 & 6 & 7 & 8 & 9\end{array}$

Library of Congress Cataloging in Publication Data

Domhoff, G. William.

The mystique of dreams.

Bibliography: p.

Includes index.

1. Dreams. 2. Stewart, Kilton, 1902- 3. Utopias. 4. United States-Civilization-1945- 5. Senoi (Malaysian people)-Psychology.

6. Senoi (Malaysian people)-Social life and customs. I. Title. BF1078.D58 $1986 \quad 154.6 ’ 3 \quad 85-970$

ISBN 0-520-05504-7 